\title{
Jeremy Bentham, a pioneer
}

\section{Oriol Caudevilla Parellada ${ }^{1}$}

"The day may come, when the rest of the animal creation may acquire those rights which never could have been withholden from them but by the hand of tyranny. The French have already discovered that the blackness of the skin is no reason why a human being should be abandoned without redress to the caprice of a tormentor. ${ }^{*}$ It may come one day to be recognized, that the number of the legs, the villosity of the skin, or the termination of the os sacrum, are reasons equally insufficient for abandoning a sensitive being to the same fate. What else is it that should trace the insuperable line? Is it the faculty of reason, or, perhaps, the faculty of discourse? But a full-grown horse or dog is beyond comparison a more rational, as well as a more conversable animal, than an infant of a day, or a week, or even a month, old. But suppose the case were otherwise, what would it avail? the question is not, Can theyreason? nor, Can thy talk? but, Can they suffer?"

Jeremy Bentham, "Limits between Private Ethics and the Art of Legislation," §-1 Of the Limits of the Penal Branch of Jurisprudence, in An Introduction to the Principles of Morals and Legislation [Printed: 1780; Published: 1789; Reprint of the London Edition of 1823] (London, 1907; Online at Library of Economics and Liberty).

${ }^{1}$ Lawyer. Member of ADS Research Group (UAB).. 


\section{1.- Introduction.}

Jeremy Bentham, 1748-1832, was an English philosopher and one of the founders of modern utilitarianism, and he is considered to be one of the earliest proponents of animal rights. We can consider that Jeremy Bentham is in many aspects a pioneer of animal rights.

Utilitarianism is the idea that the moral worth of an action is determined solely by its utility in providing happiness or pleasure as summed among all sentient beings. Bentham described it as "the greatest happiness or greatest felicity principle"

Utilitarianism is an ethical theory according to which an action is right if its results are superior to those of any other action. The fundamental idea is to engender the greatest possible amount of happiness among the greatest number.

During the beginning of the XIXth century, an increase in consideration and respect for the rights of animals grew, along with the idea that animals should be treated in a different way. Much of this change in attitude was due to the influence of Jeremy Bentham who changed the philosophies of many people by changing the way they looked at animals. Rather than regarding them as inferior to human beings because of their inability to reason, Bentham applied ethical utilitarianism to animals. He said that because animals suffer, their happiness and wellbeing is relevant and that it is the capacity for suffering that gives all sentient beings the right to equal consideration

He argued that it was the ability to suffer rather than the ability to reason that should provide the benchmark, or what he called the "insuperable line", of how we treat other animals. He pointed out that if rationality was the main criterion of who ought to have rights and how we treated other animals than many humans would for similar 
reasons be treated as objects in much the same way as animals, for example babies and the mentally disabled.

\section{2.- Some previous philosophers: Descartes and Kant.}

On the one hand, Descartes considered that human beings possess the distinguishing feature of being res cogitans. That is, humans possess a substantial mind or soul. This mind is the locus of feelings, thought, rationality, and is the basis for free will and moral values. By contrast, Descartes thought that animals have no mind or soul and are therefore ultimately only res extensa, or "extended, physical, stuff." Animals are essentially just fleshy machines or automata merely. No "soul" was reflected in their eyes and similarly no real pain was reflected in their apparent pain behavior.

As a consequence of lacking souls they also lack consciousness and cannot feel pleasure or pain. Descartes's teaching is also Christian doctrine, and Descartes accepted the teaching that humans have souls created by God but animals do not. And since soul is identical to mind, if animals have no soul, they are also lacking in mind.

In the other hand, Kant consideed that far as animals are concerned, we have no direct duties. Animals are not self-conscious, and are there merely as a means to an end. Their end is man.

Here Kant adopts the same view that Descartes does in asserting that animals are lacking in consciousness. Even the second version of Kant's categorical imperative enjoins people to "treat other persons (or rational beings) as ends but never as means." But Kant allows humans to treat non-humans as they will.

In 1780, the same year that Kant's Lectures were published, Bentham completed his Introduction to the Principles of Morals and Legislation. Speaking of animals, Bentham answered Kant definitively: 
The question is not, Can they reason? nor, Can they talk? but, Can they suffer? Here Bentham the utilitarian shows that rationality is secondary to well-being and value. Pleasures and pains form the foundation of a person's treatment toward sentient beings. Bentham implies that if you cause pain to sentient beings, then you have acted immorally. So in this way utilitarianism comes across as a more compassionate philosophy than Kant's deontology.

\section{3.- Comparison of two forms of utilitarianism: Jermey Bentham vs. Peter}

\section{Singer.}

Bentham's utilitarianism, as Emilie Dardenne exposes, can be seen as more hedonistic, its goal being to maximise the happiness of individuals:

By the principle of utility is meant that principle which approves or disapproves of every action whatsoever according to the tendency it appears to have to augment or diminish the happiness of the party whose interest is in question: or, what is the same thing in other words to promote or to oppose that happiness. I say of every action whatsoever, and therefore not only of every action of a private individual, but of every measure of government.

J. Bentham, An Introduction to the Principles of Morals and Legislation [1780], New York: Dover, 2 (...)

In the other hand, Singer appears as a proponent of preference utilitarianism, which tends to maximise the satisfaction of individual preferences. This can be seen in the following introduction of the equal consideration of interests principle when compared to Bentham's and Mill's classical utilitarian precept:

The way of thinking I have outlined is a form of utilitarianism. It differs from classical utilitarianism in that "best consequences" is understood as meaning what, on balance, furthers the interests of those affected, rather than merely what increases pleasure and 
dA derecho ANIMAL la web center de los animales con derecho

reduces pain. (It has, however, been suggested that classical utilitarians like Bentham and John Stuart Mill used "pleasure" and "pain" in a broad sense that allowed them to include achieving what one desired as a "pleasure" and the reverse as a "pain").

P. Singer, Practical Ethics, Cambridge: Cambridge University Press, 1993 (2nd edition), p. 14. 